\title{
Akut Akciğer Kontüzyonu Oluşturulan Ratlarda Carnosol ve Deksametazonun Tedavide Etkinliğinin Karşılaştırılması
} The comparison of treatment effectiveness of carnosol and dexamethasone in rats with lung contusion

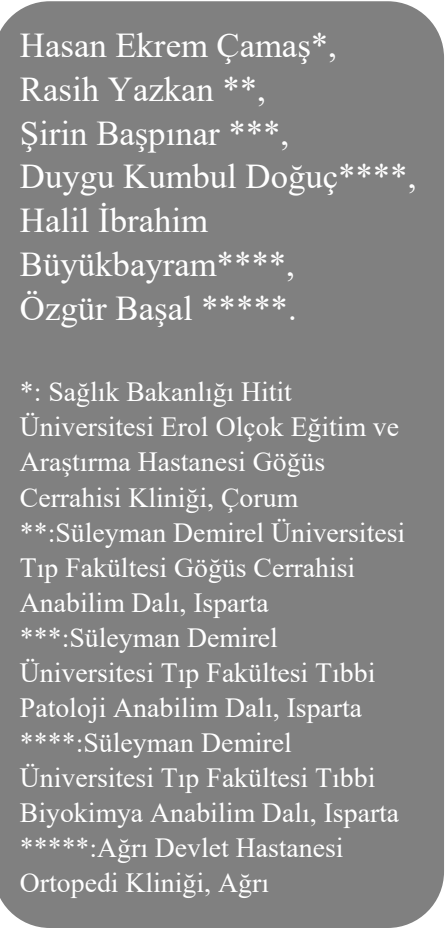

Yazışma Adresi:

Hasan Ekrem Çamaş

T.C. Sağlık Bakanlığı Hitit

Üniversitesi Erol Olçok Eğitim

ve Araştırma Hastanesi, Göğüs

Cerrahisi Kliniği. Çepni Mah.

İnönü Caddesi No:176

Merkez ÇORUM

Email:hasanekremcamas@hot mail.com

Tlf:05415691352

\section{$\ddot{O} z$}

Amaç

Travma sonrası alveollerde meydana gelen aşırı gerilme ve yırtılma, alveollerin bronşiollerden ayrılması, intraalveolar kanama, interstisyel ödem ve sonuçta meydana gelen alveolokapiller hasar akciğer kontüzyonu olarak ifade edilir. Son yıllarda deneysel akciğer kontüzyonu modeli üzerinde antioksidanların etkileri ile ilgili çalışmaların sayısı giderek artmaktadır. $\mathrm{Bu}$ çalışmanın amacı travmatik akciğer kontüzyonunda carnosol ve deksametazonun etkinliğini araştırmaktır.

\section{Gereç ve Yöntem}

Çalışmada toplam 50 adet 6-8 aylık 180-220 gr ağırlık aralığında Wistar Albino cinsi dişi sıçanlar kullanıldı. Ratlar kendi aralarında eşit şekilde $(\mathrm{n}=10)$ beş ana gruba ayrıldı. Ratlar sham grubu, sadece kontüzyon oluşturulan kontrol grubu, akciğer kontüzyonu oluşturulduktan 30 dakika sonra carnosol verilen carnosol grubu, akciğer kontüzyonu oluşturulduktan 30 dakika sonra deksametazon verilen deksametazon grubu, akciğer kontüzyonu oluşturulduktan 30 dakika sonra carnosol ve deksametazon birlikte verildiği carnosol+deksametazon grubu olarak 5 gruba ayrıldı. 48 saat sonra ratlar anestezi altında sakrifiye edildi. Sağ akciğer dokusu hem histopatolojik inceleme, hem de biyokimyasal inceleme için alındı. Sakrifiye edilirken alınan kan örneği ise biyokimyasal inceleme için değerlendirildi.

\section{Bulgular}

Serum ve doku örnekleri; total oksidan, total antioksidan ve oksidatif stres düzeyler ölçülerek ve histopatolojik değişiklikler bakılarak incelendi. Çalışmamızda carnosol ve deksametazon verilen grupların patolojik incelemesinde interstisyel ödem $(p=0,048)$, interstisyel hemoraji $(p=0,014)$ ve alveolar konjesyon $(p<0,01)$ açısından kontrol grubuna göre istatiksel olarak anlamlı düzelme gösterdiği 
anlaşılmıştır. Grupların biyokimyasal incelenmesinde travma modelinde TOS değeri en yüksek olup, tedavi gruplarında daha düşük olmasına rağmen tüm gruplar arasında istatistiksel olarak anlamlı fark tespit edilmedi.

\section{Sonuc}

Sonuç olarak; akciğer kontüzyon oluşturulan sıçanlarda kullandığımız carnosolun ve deksametazonun; kontüzyonun olumsuz etkilerini önlemedeki etkinliğinin, özellikle histopatolojik değerlendirmeler göz önüne alındığında olumlu olabileceği sonucuna varılmıştır.

Anahtar kelimeler: Akciğer, kontüzyon, carnosol, deksametazon, rat

\section{Abstract}

Aim

Excessive stretching and tearing in the alveoli after trauma, separation of the alveoli from the bronchioles, intraalveolar hemorrhage, interstitial edema and alveolocapillary damage resulting from the trauma are expressed as lung contusion. In recent years, the number of studies on the effects of antioxidants on the experimental lung contusion model has been increasing steadily. The aim of this study is to investigate the efficacy of carnosol and dexamethasone in traumatic lung contusion.

\section{Material and Method}

In this study 50 Wistar Albino female rats in a weight range of 180-220 $\mathrm{g}$ and in a age range of 6-8 months were used. The rats were divided into five equal main groups $(\mathrm{n}=10)$. Groups were designed as; sham group, control group with only lung contusion, carnosol group which are given carnosol 30 minutes after lung contusion, dexamethasone group which are given dexamethasone 30 minutes after lung contusion and carnosol dexamethasone group which were administered carnosol and dexamethasone 30 minutes after lung contusion. After 48 hours, the rats were sacrificed under anesthesia. Right lung tissue was taken for both histopathological examination and biochemical examination. Blood samples taken were evaluated for biochemical examination.

\section{Results}

Total oxidant, total antioxidant and oxidative stress levels were measured and histopathologic changes were examined in the serum and tissue samples. In our study, pathologic examination of carnosol and dexamethasone groups showed statistically significant improvement in terms of interstitial edema $(\mathrm{p}=0,048)$, interstitial hemorrhage $(\mathrm{p}=0,014)$ and alveolar congestion $(p<0,01)$ compared to the control group. The TOS value was lower in the treatment groups and the highest TOS value was in the trauma model but there was no statistically significant difference between all groups.

\section{Conclusion}

As a result; carnosol and dexamethasone used in lung contusion-induced rats; can have an effect of avoiding adverse effects of contusion, especially when histopathological evaluations are taken into consideration.

Keywords: lung, contusion, carnosol, dexamethazone, rat

\section{GÍRIŞ}

Parankimal yaralanmalar penetran veya şiddetli künt yaralanmalar sonucu ortaya çıkabilir. Travma hastalarının yaklaşık 1/3'ünde akciğer parankiminde yaralanma izlenmektedir (1). 1971 yılında Morgagni tarafindan tarif edilen akciğer kontüzyonu gögüs travmasına bağlı olarak sik görülen bir yaralanmadır. Akciğer kontüzyonu parankimal yaralanmalar içerisinde $\% 17-70$ gibi bir oran ve sahip olduğu potansiyel morbidite ve mortalite özelliği nedeniyle önemli bir yere sahiptir (1). Hem künt hem de penetran yaralanmalarla birlikte 
görülmekte olup, sıklıkla motorlu araç kazalarında göğsün direksiyon ya da kapıya çarpması nedeniyle görülür. Ayrıca yüksekten düşme, blast tarzındaki yaralanmalar ve yüksek hızlı mermilerle de görülebilir (2).

Pulmoner kontüzyonlu hastalarda dispne, takipne, hemoptizi, siyanoz ve hipotansiyon s1k görülen semptomlardır. Pulmoner kontüzyonda primer patoloji alveollerin içinde ve intersitisyel alanda anormal sivı birikerek, bronşiyollerde ve alveollerde gaz değişiminin bozulması ile hipoksemi ve hiperkarbi oluşmasıdır. $\mathrm{Bu}$ hastalarda hızlı klinik kötüleșme görülebileceği için, tüm hastalar erken dönemde yakından takip edilmelidir. Eğer kontüzyon masif tarzda ise aspirasyon, bakteri pnömonisi, ARDS gibi majör komplikasyonlar gelişebilir. Serbest oksijen radikalleri, adezyon molekülleri ve sitokinler doku ve kan damarlarındaki endotel ve nötrofiller arasındaki ilișkinin belirleyicileridir. Yaralanma sirasında hipovolemi, arteryal tromboz ve direkt arter hasarı yüzünden dokularda nekroz gelişebilir. Nekrozdan önce kan akımının tekrar sağlanması bu süreci tersine çevirebilir. Bununla birlikte, reperfüzyon sirasinda serbest oksijen radikallerinin olușması genellikle doku hasarını daha da ağırlaștırır. Akciğer kontüzyonlu hastalarda serbest radikallerin bu zararlı etkilerini azaltmak gerekmektedir.

İskemi-reperfüzyon hasarının önlenmesinde endojen antioksidan sistemler etkili olduğu gibi eksojen antioksidan sistemler de etkilidir. Eksojen antioksidanlar konusunda literatürde çok farklı ilaçlar ve gıdalar üzerinde çalışmalar bulunmaktadır (3). Biberiye (Rosmarinus officinalis) bitkisinden elde edilen carnosol bir çok çalışmada antioksidan özelliği üzerinde durulmuştur. Carnosolun antikarsinojenik, antiproliferatif, antimikrobiyal etkilerinin yanı sıra antioksidan özelliklerinin de olduğu gösterilmiştir (4). Ji-Hong Yao ve ark. (5) yapmış olduğu karaciğer iskemi reperfüzyon modelinde carnosolun antioksidan, antiproliferatif ve antikanser etkisi üzerinde durulup biyokimyasal ve histopatolojik etkileri araştırılmıştır. Xiao-Feng Tian ve ark. (6) yapmış olduğu barsak iskemi reperfüzyonunun sebep olduğu akciğer hasarında carnosolun koruyucu etki modelinde proinflamatuar sitokin olan interlökin-6 (IL-6) down regülasyonu etkisi üzerinde durmuşlardır.

Son 60 yıldır travmaya bağlı akciğer kontüzyonunda belirgin ilerleme sağlanmasına rağmen tedavide steroid kullanımının yeri net değildir. Buna rağmen bazı verilerde kısa süreyle yüksek doz kortikosteroid vermek önerilmektedir. Deksametazon bir kortikosteroid türevidir. Şiddetli inflamatuar patolojilerde kullanılan antienflamatuar ve potent immunsüpresif bir ajandır. Fibroblast ve makrofajların diferansiyasyonu ve proliferasyonu glukokortikoidler tarafindan inhibe edilmektedir. Ayrıca birçok proinflamatuar endotelyal hücrelerin cevabını inhibe etmektedir.

Sonuç olarak toraks travmaları sonrası gelişen akut akciğer kontüzyonu göğüs cerrahlarının oldukça sık karşılaştıkları ve tedavisi hakkında literatürde birçok deneysel çalışmanın olduğu bir klinik tablodur. Bu çalışmada kontüzyon tedavisi için en doğru ajanı bulmak amaçlanmıştır. Bizim çalışmamızın amacı akciğer kontüzyonunda mortalite ve morbiditenin azalması için erken dönemde uygulanan carnosol ve deksametazonun etkinliğinin araştırılmasıdır.

\section{MATERYAL VE METOD}

$\mathrm{Bu}$ çalışma, deney hayvanlarının bilimsel amaçla kullanılabilmesi için Süleyman Demirel Üniversitesi Tıp Fakültesi Etik Kurulundan onay alınarak (01.09.2016 tarih ve 02 say1l karar) etik kurul kurallarına uygun bir șekilde Süleyman Demirel Üniversitesi Tıp Fakültesi Deney Hayvanları Araştırma Laboratuvarı, Tibbi Biyokimya ve Tibbi Patoloji Anabilim Dalı Laboratuvarlarında gerçekleştirilmiştir. Ayrıca Süleyman Demirel Üniversitesi Bilimsel 
Araştırma Projeleri Yönetim Birimi tarafından 4564-TU1-16 proje numaras1 ile desteklenmiştir.

Ratlar deney öncesi tel kafeslerde 12 saat gece 12 saat gündüz sirkadiyen ritimde, ortam sıcaklığı $20-26^{\circ} \mathrm{C}$ olacak şekilde 10 gün süre ile tutuldular ve gözlemlendiler. Deneyden 12 saat önce su hariç beslenmeleri durduruldu. Tüm ratların bakımı, Tıbbi Araştırmalar Ulusal Derneği tarafından biçimlendirilen 'Deney Hayvanlarının Bakım Prensipleri'ne ve Laboratuvar Hayvanı Kaynakları Enstitüsü tarafından hazırlanıp Ulusal Sağlık Enstitüsü tarafindan yayınlanan, Laboratuvar Hayvanlarının Bakım ve Kullanımı için Kılavuz'una uygun olarak yapıldı.

Bu çalışmada toplam 50 adet 6-8 aylık 180-220 gr ağırlık aralığında Wistar Albino cinsi dişi sıçanlar kullanıldı. Sıçanlar Süleyman Demirel Üniversitesi Tıp Fakültesi Deney Hayvanları Araştırma Laboratuvarı Üretim Biriminden temin edildi. Ratlar kendi aralarında eşit şekilde $(\mathrm{n}=10)$ beş ana gruba ayrıldı.

Birinci grup; sham, ikinci grup; sadece kontüzyon oluşturulan, üçüncü grup; akciğer kontüzyonu olușturulduktan 30 dakika sonra carnosol verilen, dördüncü grup; akciğer kontüzyonu sonrasinda deksametazon verilen, beşinci grup; akciğer kontüzyonu olușturulduktan 30 dakika sonra carnosol ve deksametazon birlikte verilen rat modeli grupları olarak planland.

Grup 1; Sham grubundaki ratlarda kontüzyon modeli oluşturulmadi. Deney sonunda ratlar anestezi altında sakrifiye edilerek sağ akciğer dokusu histopatolojik ve biyokimyasal inceleme için alındı. Sakrifiye edilirken alınan kan örneği ise biyokimyasal inceleme için değerlendirildi.

Carnosol grubundan 2 ratın ex olması üzerine basit rastgele yöntemle seçilen bir rat carnosol grubuna dahil edildi. $\mathrm{Bu}$ grupta kalan 9 rat ile çalışma tamamlandi.

Grup 2; Kontrol (kontüzyon) grubundaki ratlarda, kontüzyon modeli oluşturulup herhangi bir ilaç verilmeyerek; 48 saat sonra ratlar anestezi altında sakrifiye edildi. Sağ akciğer dokusu histopatolojik ve biyokimyasal inceleme için alındı. Sakrifiye edilirken alınan kan örneği ise biyokimyasal inceleme için değerlendirildi. Bir adet rat akciğer kontüzyonu oluşturulduktan yaklaşık 1 saat sonra ex olduğu için çalışma dışında tutuldu. İstatistiksel analizlere 9 rat dahil edildi.

Grup 3; Carnosol grubundaki ratlarda, kontüzyon modeli oluşturulduktan $30 \mathrm{dk}$ sonra intraperitonel yolla $5 \mathrm{mg} / \mathrm{kg}$ dozda carnosol verildi. Bu işlemin ardından kontüzyon modeli oluşturulup, 48 saat sonra ratlar anestezi altında sakrifiye edildi. Sağ akciğer dokusu histopatolojik ve biyokimyasal inceleme için alındı. Sakrifiye edilirken alınan kan örneği ise biyokimyasal inceleme için değerlendirildi. 2 adet rat akciğer kontüzyonu olduktan hemen sonra ex olması üzerine çalışma dışında tutuldu. Sham grubundan bir adet rat alınarak carnosol grubuna eklendi. Sonuç olarak hem sham grubunda, hem de carnosol grubunda toplam 9 adet rat ile çalışma tamamlandi.

Grup 4; Deksametazon grubundaki ratlarda, kontüzyon modeli oluşturulup $30 \mathrm{dk}$ sonra intraperitonel yolla $10 \mathrm{mg} / \mathrm{kg}$ dozda deksametazon verildi. Deksametazon verildikten 48 saat sonra ratlar anestezi altında sakrifiye edildi. Sağ akciğer dokusu histopatolojik ve biyokimyasal inceleme için alındı. Sakrifiye edilirken alınan kan örneği ise biyokimyasal inceleme için değerlendirildi.

Grup 5; Carnosol ve deksametazon grubundaki ratlarda, kontüzyon modeli oluşturulduktan 30 $\mathrm{dk}$ sonra intraperitonel yolla $5 \mathrm{mg} / \mathrm{kg}$ dozda carnosol ve intraperitonel yolla $10 \mathrm{mg} / \mathrm{kg}$ dozda deksametazon verildi. 48 saat sonra ratlar anestezi altında sakrifiye edilerek sağ akciğer dokusu histopatolojik ve biyokimyasal inceleme için alındı. Sakrifiye edilirken alınan kan örneği ise biyokimyasal inceleme için değerlendirildi. 


\section{Travma Modeli}

Raghavendran ve ark.nın (7) tanımladığı izole iki taraflı pulmoner kontüzyon (PK) modelinin modifiye edilmesi ile oluşturulan bilateral PK modeli kullanıldı. 1 metre yükseklikten $200 \mathrm{gr}$ ağırlık ratların toraks ön duvarı üzerine düşürülerek akciğer kontüzyonu oluşturuldu. Ortaya çıkan enerji $E=m g h$ formülü ile $(E$ : enerji, g: yer çekimi; $9.8 \mathrm{~m} / \mathrm{s} 2$, h: yükseklik; $100 \mathrm{~cm}$ ve m: düşürülen ağırlık; $0.2 \mathrm{~kg}) 1,96$ joule olarak hesaplandı. Sonuç olarak ratlara 1,96 joule enerji uygulanarak pulmoner kontüzyon oluşturuldu.

\section{Anestezi ve Uygulama}

Ratlara, kontüzyon modeli oluşturulurken anestezi sağlayabilmek için $10 \mathrm{mg} / \mathrm{kg}$ xylazine $\mathrm{HCl}+50 \mathrm{mg} / \mathrm{kg}$ ketamin $\mathrm{HCl}$ intraperitoneal uyguland1. Kontüzyon modeli oluşturulduktan 48 saat sonra ise sakrifikasyon yapılması için $10 \mathrm{mg} / \mathrm{kg}$ xylazine $\mathrm{HCl}+90 \mathrm{mg} / \mathrm{kg}$ ketamin $\mathrm{HCl}$ intraperitoneal uygulandi. Anestezi altında sakrifiye edilen ratlara torakotomi yapılarak sağ akciğer dokuları çıkarıldı. Çıkarılan her bir akciğer dokusunun yaklaşık yarısı histopatolojik incelemeye, kalan yarısı ise biyokimyasal incelemeye alındı. Her bir sağ akciğer dokusu patolojik inceleme yapılabilmesi için \%10'luk formalinde fikse edildi. Sonrasında doku takibi yapılarak parafin bloklara gömüldü. Gömülen bu dokulardan $5 \mu \mathrm{m}$ 'lik kesitler alınarak rutin hematoksilen eozin ile boyaması yapıldı. Ardından akciğer dokuları çift kör olarak (gruplar bilinmeden) değerlendirildi.

\section{Doku Homojenatı ve Serum Örneklerinin Hazırlanması}

Ratların kan örnekleri jelli biyokimya tüplerine alınarak soğuk ortamda laboratuvara transfer edildi. Laboratuvarda pihtılaşması tamamlanan kanlar, soğutmalı santrifüj cihazında (Nüve NF1200R,Türkiye) 3000 rpm'de 10 dakika santrifüj edildi. Böylece elde edilen serumlar çalışma gününe kadar $-20^{\circ} \mathrm{C}$ 'de saklandı. Ratlar sakrifiye edildikten sonra akciğer dokuları cam tüplere alınarak üzerlerine $10 \mathrm{mM} \mathrm{pH} \mathrm{7,4}$ olan fosfat tamponu eklendi. Soğuk ortamda laboratuvara transfer edilen akciğer dokuları soğuk fosfat tamponu ile yıkanarak dokuların kan gibi artıklardan temizlenmesi sağland. Daha sonra hassas terazi ile ağırlıkları tartıldı ve 10 kat $10 \mathrm{mMph} 7,4$ fosfat tamponu eklenerek homojenizasyon işlemine başland. Homojenizasyon işleminde dokular önce doku parçalayıcı ile (Janke\&Kunkel IKA Ultra Turrax T25, Almanya) parçalandı, daha sonra ultrasonik homojenizatör ile (Bandelin Sonopuls HD 2070, Almanya) 30 sn sonike edildi. Elde edilen doku homojenatları, 3000 rpm'de 10 dk santrifüj edildi (Nüve NF1200R, Türkiye), daha sonra süpernatantları eppendorf tüplerine alınarak çalışma gününe kadar $-20^{\circ}$ C'de saklandi.

\section{TAS (Total Antioxidant Status) ve TOS (Total Oxidant Status) Düzeylerinin Analizi}

Serum ve doku örneklerinin TAS ve TOS düzeyleri Rel Assay Diagnostics Marka kitlerle otoanalizörde (Beckman Coulter AU 680,Japonya) spektrofotometrik olarak çalışıldı. TAS düzeyi çalışılırken; numunede bulunan antioksidan maddeler, kit içindeki reaktiflerden biri olan koyu mavi-yeşil renkteki ABST radikal solüsyonunu renksiz forma redüklemiştir ve reaksiyon karışımının $660 \mathrm{~nm}$ deki absorbans değişimi ölçüldü. Absorbans değişimi, numunede bulunan TAS düzeyi ile doğru orantılı idi. Yöntem, stabil antioksidan standart solüsyonu (E vitamini analoğu) Trolox Equivalent ile kalibre edildi. TOS düzeyi ölçümü için; numunede bulunan oksidan maddeler, ferröz iyon şelatör kompleksini ferrik iyon haline okside edildi. Ferrik iyon formu, asidik ortamda kromojen ile renkli bir kompleks meydana getirdi. Renk oluşumu; numunedeki oksidan moleküllerin miktarı ile doğru orantılı olduğundan, spektrofotometrik olarak ölçüldü ve TOS değeri elde edildi. Yöntem, hidrojen peroksit ile kalibre edildi. 
Elde edilen TAS ve TOS değerleri kullanılarak OSI (Oxidative Stress Index) değerleri hesaplandı. OSI (arbitrary unit) $=$ TOS $(\mu \mathrm{mol}$ $\mathrm{H} 2 \mathrm{O} 2 \mathrm{Eq} / \mathrm{L}) / \mathrm{TAS}(\mu \mathrm{molTroloxEq} / \mathrm{L}) \times 100$ (8).

\section{İstatiksel Analiz ve Değerlendirme}

Veriler bilgisayar ortaminda SPSS 22.0 (Statistical Package of Social Sciences Versiyon 22.0) programı kullanılarak değerlendirildi. Tanımlayıcı analizler, ki kare, Kruskal Wallis analizleri uyguland. p değerinin $0,05^{\prime}$ in altında olduğu durumlar istatistiksel olarak anlamlı kabul edildi.

Kruskal Wallis analizlerinin anlamlı olduğu durumlarda farkın kaynaklandığı grubu belirlemek üzere Bonferroni düzeltmeli Mann Whitney U testi uyguland.

\section{BULGULAR}

\section{Histopatolojik Analiz}

\%10'luk tamponlanmış formalinde fikse edildikten sonra doku takibi yapılan akciğer dokuları parafin bloklara gömüldü. $\mathrm{Bu}$ dokulardan $5 \mu$ m'lik kesitler alınarak Hematoksilen\&Eozin (HE) ile boyand. Her bir akciğer dokusu detaylı olarak incelendi. Her akciğer kesitinde histopatolojik olarak ödem, konjesyon, hemoraji, disruption (alveolar parçalanma) ve lökosit infiltrasyonu parametrelerin herbiri ayrı ayrı değerlendirilerek skorlamaya tabi tutuldu. Lökosit infiltrasyonu parametresi 10 büyük büyütme alanındaki ekstravasküler lökositler sayılarak 0,1,2,3 skorlama yapıld1, diğer histopatolojik parametrelerin ise semikantitatif olarak patoloji yok (0), hafif $(<\% 10)$, orta $(\% 10$ $-45)$, şiddetli $(>\% 45)$ olarak değerlendirilmesi yapild1 $(7,9-11)$.

\section{İnterstisyel Ödemin Histopatolojik Analizi}

Araştırmaya dahil edilen ratların akciğer dokuları 48 saat sonra sakrifiye edilerek sham grubunun, kontrol grubunun, carnosol grubunun, deksametazon grubunun ve carnosol -deksametazon kombine grubunun interstisyel ödeme göre dağılımı Tablo 1'de görülmektedir. Sham grubunun sakrifiye edilen akciğer dokusunun histopatolojik incelenmesi sonrasinda grubun \%55,6'sinda hafif düzeyde interstisyel ödem görüldü, \%44,4'ünde ise interstisyel ödem saptanmadi. Kontrol grubunun \%33,3'ünde hafif düzeyde, \% 22,2'sinde orta düzeyde, \%11,1'inde şiddetli düzeyde interstisyel ödem görüldü; \%33,3'ünde ise interstisyel ödem saptanmadi. Carnosol grubunun \%44,4'ünde hafif düzeyde, \% 22,2'sinde orta düzeyde interstisyel ödem görülürken, \%33,3'ünde interstisyel ödem saptanmadi. Deksametazon grubunun \% 20'sinde hafif düzeyde interstisyel ödem görülürken, \%80'inde interstisyel ödem saptanmadi. Carnosol-deksametazon kombine grubunun \%50'sinde hafif düzeyde interstisyel ödem görüldü, \%50'sinde ise interstisyel ödeme rastlanmadi.

Sham, kontrol, carnosol, deksametazon ve carnosol-deksametazon kombine gruplarının interstisyel ödem açısından karşılaştırması Tablo 1'de görülmektedir. Gruplar interstisyel ödeme göre karşılaştırıldığında gruplar arasında istatistiksel olarak anlamlı fark belirlendi $(\mathrm{p}=0,048)$. Farkin kontrol grubundan kaynaklandığı saptandı. 
Tablo 1. Denek gruplarının inter stisyel ödem açısından kar şılaştırılması

\begin{tabular}{|l|c|c|c|}
\hline Interstisyel Ödem & $\begin{array}{c}\text { Yok-Hafif } \\
\mathbf{n}(\%)\end{array}$ & $\begin{array}{c}\text { Orta-Şiddetli } \\
\mathbf{n}(\%)\end{array}$ & $\mathrm{P}^{*}$ \\
\hline Sham (n=9) & $9(100)$ & - & \\
\hline Kontrol (n=9) & $6(66,7)$ & $2(22,2)$ & $\mathbf{0 , 0 4 8}$ \\
\hline Carnosol (n=9) & $7(77,8)$ & - & \\
\hline Deksametazon (n=10) & $10(100)$ & - & \\
\hline Carnosol-Deksametazon (n=10) & $10(100)$ & $5(10,6)$ & \\
\hline Toplam & $42(89,4)$ & & \\
\hline
\end{tabular}

* Pearson ki-kare testi

\section{İnterstisyel Hemoraji Histopatolojik Analizi}

Sham, kontrol, carnosol, deksametazon ve carnosol-deksametazon kombine gruplarının interstisyel hemoraji açısından karşılaştırması Tablo 2'de görülmektedir. Gruplar interstisyel hemorajiye göre karşılaştırıldığında gruplar arasında istatistiksel olarak anlamlı fark belirlendi $(p=0,014)$. Farkın kontrol grubundan kaynaklandığı saptandı.

Tablo 2. Denek gruplarının inter stisyel hemoraji açısından karşılaştır ılması

\begin{tabular}{|l|c|c|c|}
\hline Hemoraji & $\begin{array}{c}\text { Yok-Hafif } \\
\mathbf{n}(\%)\end{array}$ & $\begin{array}{c}\text { Orta-Şiddetli } \\
\mathbf{n}(\%)\end{array}$ & P* \\
\hline Sham(n=9) & $9(100)$ & - & \\
\hline Kontrol(n=9) & $3(33,3)$ & $6(66,7)$ & \\
\hline Carnosol(n=9) & $8(88,9)$ & $1(11,1)$ & $\mathbf{0 , 0 1 4}$ \\
\hline Deksametazon(n=10) & $6(60)$ & $4(40)$ & \\
\hline Carnosol-Deksametazon(n=10) & $8(80)$ & $2(20)$ & \\
\hline Toplam & $34(72,3)$ & $13(27,6)$ & \\
\hline
\end{tabular}

* Pearson ki-kare testi

\section{Alveolar Konjesyon Histopatolojik Analizi}

Sham, kontrol, carnosol, deksametazon ve carnosol-deksametazon kombine gruplarının alveolar konjesyon açısından karşılaştırması Tablo 3'de görülmektedir. Gruplar alveolar konjesyona göre karşılaştırıldığında gruplar arasında istatistiksel olarak anlamlı fark belirlendi $(p<0,01)$. Farkın kontrol grubundan kaynaklandığı saptandı. 
Tablo 3. Denek gruplarının alveolar konjesyon açısından karşılaştırılması

\begin{tabular}{|l|c|c|c|}
\hline Konjesyon & $\begin{array}{c}\text { Yok-Hafif } \\
\mathbf{n}(\%)\end{array}$ & $\begin{array}{c}\text { Orta-Şiddetli } \\
\mathbf{n}(\%)\end{array}$ & $\mathrm{p}^{*}$ \\
\hline Sham(n=9) & $9(100)$ & - & \\
\hline Kontrol(n=9) & $2(22,8)$ & $7(77,8)$ & \\
\hline Carnosol(n=9) & $6(66,7)$ & $3(33,3)$ & $<\mathbf{0 , 0 1}$ \\
\hline Deksametazon(n=10) & $9(90)$ & $1(10)$ & \\
\hline Carnosol-Deksametazon(n=10) & $10(100)$ & - & \\
\hline Toplam & $36(76,6)$ & $11(23,4)$ & \\
\hline
\end{tabular}

* Pearson ki-kare testi

\section{Alveolar Parçalanma Histopatolojik Analizi}

Sham, kontrol, carnosol, deksametazon ve carnosol-deksametazon kombine gruplarının alveolar parçalanma açısından karşılaştırması Tablo 4'de görülmektedir. Gruplar alveolar parçalanmaya göre karşılaştırıldığında gruplar arasında istatistiksel olarak anlamlı fark bulunmadı $(p=0,308)$.

Tablo 4. Denek gruplarının alveolar parçalanma açısından karşılaştırılması

\begin{tabular}{|l|c|c|c|}
\hline Alveolar parçalanma & $\begin{array}{c}\text { Yok-Hafif } \\
\mathbf{n}(\%)\end{array}$ & $\begin{array}{c}\text { Orta-Şiddetli } \\
\mathbf{n}(\%)\end{array}$ & p* \\
\hline Sham (n=9) & $9(100)$ & - & \\
\hline Kontrol (n=9) & $7(77,8)$ & $2(22,2)$ & \\
\hline Carnosol (n=9) & $7(77,8)$ & $2(22,2)$ & 0,308 \\
\hline Deksametazon (n=10) & $9(90)$ & $1(10)$ & \\
\hline Carnosol-Deksametazon $(\mathbf{n = 1 0 )}$ & $10(100)$ & - & \\
\hline Toplam & $42(89,4)$ & $5(10,6)$ & \\
\hline
\end{tabular}

* Pearson ki-kare testi

\section{Lökosit İnfiltrasyonun Histopatolojik Analizi}

Sham, kontrol, carnosol, deksametazon ve carnosol-deksametazon kombine gruplarının lökosit infiltrasyonu açısından karşılaştırması Tablo 5'de görülmektedir. Gruplar lökosit infiltrasyonu göre karşılaştırıldığında gruplar arasında istatistiksel olarak anlamlı fark bulunmadı $(p=0,118)$. 
Tablo 5. Denek gruplarının lökosit infiltrasyonu açısından kar ş1laştır ılması

\begin{tabular}{|l|c|c|c|}
\hline Lökosit infiltrasyonu & $\begin{array}{c}\text { Yok-Hafif } \\
\mathbf{n}(\%)\end{array}$ & $\begin{array}{c}\text { Orta-Şiddetli } \\
\mathbf{n}(\%)\end{array}$ & $\mathrm{p}^{*}$ \\
\hline Sham(n=9) & $9(100)$ & - & \\
\hline Kontrol(n=9) & $6(66,7)$ & $3(33,3)$ & \\
\hline Carnosol(n=9) & $6(66,7)$ & $3(33,3)$ & $\mathbf{0 , 1 1 8}$ \\
\hline Deksametazon(n=10) & $10(100)$ & - & \\
\hline Carnosol-Deksametazon(n=10) & $8(80)$ & $2(20)$ & \\
\hline Toplam & $39(82,9)$ & $8(17)$ & \\
\hline
\end{tabular}

* Pearson ki-kare testi

\section{Biyokimyasal Analiz}

Sham grubunun, kontrol grubunun, carnosol grubunun, deksametazon grubunun, carnosoldeksametazon kombine grubunun doku TOS değeri açısından karşılaştırıldı. Doku TOS değerlerine göre gruplar arasında anlamlı fark vardı $(\mathrm{p}=0,009)$. Fark kontrol grubu ile deksametazon grubu $(p=0,007)$, kontrol grubu ile carnosol-deksametazon grubu $(p=0,002)$, carnosol grubu ile carnosol-deksametazon grubu $(\mathrm{p}=0,006)$ arasindan kaynaklanıyordu. Sham grubunun, kontrol grubunun, carnosol grubunun, deksametazon grubunun,carnosol-deksametazon kombine grubunun doku OSI değeri açısından karşılaştırıldı. Doku OSİ değerlerine göre gruplar arasında anlaml 1 fark vard $1(\mathrm{p}=0,001)$. Fark carnosol grubu ile deksametazon grubu $(\mathrm{p}=0,001)$, carnosol grubu ile carnosol-deksametazon grubu $(\mathrm{p} \leq 0,001)$ arasından kaynaklanıyordu (Tablo 6).

Tablo 6. Tüm gruplara ait biyokimyasal parametrelerin karşılaştırılması

\begin{tabular}{|c|c|c|c|c|c|c|}
\hline & $\begin{array}{c}\text { Sham } \\
(\text { Ort } \pm \text { SS) })^{* *}\end{array}$ & $\begin{array}{c}\text { Kontrol } \\
(\text { Ort } \pm \text { SS })\end{array}$ & $\begin{array}{c}\text { Carnosol } \\
(\text { Ort } \pm \text { SS })\end{array}$ & $\begin{array}{c}\text { Deksametazon } \\
(\text { Ort } \pm \text { SS })\end{array}$ & $\begin{array}{c}\text { CarnosolDeksa- } \\
\text { metazon } \\
(\text { Ort } \pm \text { SS })\end{array}$ & $\mathbf{p}^{*}$ \\
\hline Doku TOS & $32,25 \pm 4,28$ & $30,87 \pm 3,11$ & $32,00 \pm 3,20$ & $36,64 \pm 4,27$ & $41,90 \pm 11,89$ & $\mathbf{p}=\mathbf{0 , 0 0 9}$ \\
\hline Serum TOS & $10,60 \pm 5,29$ & $15,30 \pm 8,70$ & $7,58 \pm 4,42$ & $9,40 \pm 6,58$ & $10,55 \pm 7,42$ & $\mathrm{p}=0,08$ \\
\hline Doku TAS & $0,61 \pm, 09$ & $0,61 \pm 0,12$ & $0,65 \pm 0,07$ & $0,59 \pm 0,04$ & $0,50 \pm 0,18$ & $\mathrm{p}=0,270$ \\
\hline Serum TAS & $1,39 \pm 0,19$ & $1,61 \pm 0,50$ & $1,33 \pm 0,12$ & $1,50 \pm 0,13$ & $1,47 \pm 0,18$ & $\mathrm{p}=0,167$ \\
\hline Doku OSİ & $5,34 \pm 0,78$ & $5,21 \pm 1,25$ & $4,92 \pm 0,45$ & $6,16 \pm 0,79$ & $12,35 \pm 13,03$ & $\mathbf{p}=\mathbf{0 , 0 0 1}$ \\
\hline Serum OSİ & $0,75 \pm 0,35$ & $0,96 \pm 0,45$ & $0,55 \pm 0,30$ & $0,60 \pm 0,36$ & $0,68 \pm 0,39$ & $\mathrm{p}=0,119$ \\
\hline
\end{tabular}

* Kruskal Wallis analiz testi

**Ort:Ortalama,SS: Standart Sapma 


\section{TARTIŞMA}

Genç erişkin nüfusun en sık ölüm nedenini oluşturmakta olan travma, siklıkla trafik kazaları, iş kazaları ve şiddet olayları nedeniyle görülmekte olup, gögüs travmaları, kafa ve ekstremite travmalarından sonra üçüncü sırada yer almaktadır (12). Tüm travma ölümleri içerisinde, göğüs travmalarına bağlı ölümler \% 25 yer kaplar (13). Pulmoner kontüzyonda primer patoloji alveollerin içinde ve interstisyel alanda anormal sıvı birikerek, bronşiyollerde ve alveollerde gaz değişimin bozulması ile hipoksemi ve hiperkarbi oluşmasıdır. $\mathrm{Bu}$ hastalarda hızlı klinik kötüleșme görülebileceği için, tüm hastalar erken dönemde yakından takip edilmelidir.

Serbest oksijen radikalleri, adezyon molekülleri ve sitokinler doku ve kan damarlarındaki endotel ve nötrofiller arasındaki ilişkinin belirleyicileridir. Yaralanma sirasında hipovolemi, arteryal tromboz ve direkt arter hasarı yüzünden dokularda nekroz gelişebilir. Nekrozdan önce kan akımının tekrar sağlanması bu süreci tersine çevirebilir. Bununla birlikte, reperfüzyon sırasında serbest oksijen radikallerinin oluşması genellikle doku hasarını daha da ağırlaştırır. Akciğer kontüzyonlu hastalarda serbest radikallerin bu zararlı etkilerini azaltmak gerekmektedir.

Çalışmamızda antiinflamatuvar ajan olarak rat gruplarında, deksametazon ve carnosol kullanıld1. Akciğer dokusu biyokimyasal ve histopatolojik olarak değerlendirildi.

Akciğer kontüzyonunda patofizyolojik ve hücresel düzeyde gelişen değişiklikleri araştıran çalışmalar yapabilmek için anlamlı ve tekrarlanabilir hayvan deneylerine ihtiyaç vardır. Akciğer kontüzyonu için çeșitli modeller geliștirilmiştir (14). Bu modellerde domuz, köpek, rat gibi birçok farklı deney hayvanları kullanılmıştır.Literatürdeki deneysel modellerin temel amac1; belli gruplara belli miktarda travma şiddetini standart olarak uygulayabilmek temeline dayanmaktadir (15, $16,17)$.
Raghaverden ve arkadaşlarının yapmış olduğu çalışmada $1.8,2.0,2.2,2.45$ ve 2.7 joule (J) enerji uygulanmış ve mortalitenin en az, kontüzyonun en fazla olduğu enerji değerinin 2.45 joule olduğu tespit edilmiştir(7). Bunun üzerine daha önceden bildirilmiş akciğer kontüzyon modelleri uyarlanarak genel anestezi altında ortalama ağırlıkları 200- 230 gram olan Wistar-Albino cinsi dişi siçanlara $2.0 \mathrm{~J}$ enerji uygulayarak kontüzyon amaçlandı.

Çalışmamızda akciğer kontüzyon modelinde antioksidan özelliğini araştırmak için biberiye bitkisinde doğal olarak bulunan phenolicditerpene türevi olan carnosol kullanılmıştır. Literatur incelemelerinde carnosolun in vitro antikanser, antioksidan ve antiproliferatif aktivitesi olduğunu gösteren çalışmalar bulunmaktadır (4).

Xiao-Fengve ark. (18) deneysel olarak yaptıkları barsak iskemi reperfüzyonun sebep olduğu akciğer hasarı modelinde, carnosolun akciğerler üzerine koruyucu etkisinin olup olmadığını araştırmışlardır. $\mathrm{Bu}$ araştırma sonucunda, deney+ilaç verilen grupta deney grubuna göre, bir serbest oksijen radikali olan myeloperoksidazın düzeylerinin azaldığını saptamışlar. $\mathrm{Bu}$ durum yazarlar tarafindan carnosolun barsak iskemi reperfüzyonunda akciğer hasarını önlemede olumlu etkisinin olduğu şeklinde değerlendirilmiştir. Bizim çalışmamızda carnosolun patolojik incelemesinde interstisyel ödem, interstisyel hemoraji ve alveolar konjesyon açısından kontrol grubuna göre anlamlı olarak düzelme gösterdiği anlaşılmıştır.

ARDS tedavisinde kortikosteroidlerin kullanımı yıllardır pek çok çalışmaya ve tartıșmaya konu olmuștur. Etki mekanizması tam olarak henüz kesinlik kazanmasa da yapılan deneysel çalışmalarla kortikosteroidlerin konağın inflamatuar medyatörlerini inhibe ettiği böylece morbidite ve mortaliteyi iyileştirdiği yönünde bilgiler mevcuttur (19).

Kortikosteroidler ve nonsteroidler bir 
araşidonik asit metabolizması basamağı olan fosfolipaz, siklooksijenaz ve NO sentaz enzimlerine etki etmek suretiyle enflamatuar yolağın üç önemli ürünü olan prostaglandin, prostosiklin ve lökotrien salınımını azaltır (20). Bununla beraber bu etki vücudun genelinde de görüleceğinden savunma mekanizması da etkilenmiş olur. ARDS tedavisinde tam olarak etki mekanizması kesinlik kazanmasa da deneysel çalışmalarda morbidite ve mortaliteyi azalttığı yönünde bilgiler mevcuttur (19). Bizim çalışmamızda deksametazonun patolojik incelemesinde interstisyel ödem, interstisyel hemoraji, alveolar konjesyon açisından kontrol grubuna göre anlamlı olarak düzelme gösterdiği anlaşılmıştır.

Mutlu ve ark.larının Çukurova Üniversitesi Neonatoloji Anabilim Dalında yapılan deneysel çalışmada 36 adet 3 günlük ratlar 4 gruba ayrılmış olup kontrol grubu hariç diğer 3 grup 10 gün boyunca $\% 90$ hiperoksiye maruz bırakılmıştır. Kontrol grubu, hiperoksi grubu, hiperoksi sonras $1 \mathrm{E}+\mathrm{C}$ vitaminleri verilen grup, hiperoksi sonrası $\mathrm{N}$-asetilsistein (NAC) verilen grup biyokimyasal olarak total antioksidan, total oksidan ve oksidatif stres ile değerlendirilmiş (21).

Çalışmanın sonucunda serum TOS düzeyleri kontrol grubu ile karşılaştırıldığında hiperoksiye maruz kalan diğer üç grupta da yüksek olarak saptanmış. $\mathrm{Bu}$ yükseklik hiperoksi ve vitamin grubunda istatistiksel olarak anlamlı imiş (kontrol ile hiperoksi arasinda $p<0,001$, kontrol grubu ile NAC grubu arasinda $\mathrm{p}=0,46$ ve kontrol grubu ile vitamin grubu arasindap $=0,008$ ). Hiperoksi grubu ile karşılaştırıldığında NAC grubunda ve vitamin grubunda TOS düzeyleri hafif derecede düșük bulunmuş. $\mathrm{Bu}$ istatistiksel olarak anlamlı değildir ( $p$ sırası ile 0,32 ve 0,99 ). NAC grubu ile vitamin grubu arasinda ise anlamlı fark bulunmamış $(p=0,64)$. Bizim çalışmamızda ise sham grubu, kontrol grubu, carnosol grubu, deksametazon grubu, carnosol ve deksametazon kombine grubu serum TOS ortalama değerleri sirasıyla $10,60 \pm 5,29 \mu \mathrm{mol}$ $\mathrm{H} 2 \mathrm{O} 2 \mathrm{Eq} / \mathrm{L}, \quad 15,30 \pm 8,70 \mu \mathrm{mol} \mathrm{H} 2 \mathrm{O} 2 \mathrm{Eq} / \mathrm{L}$, $7,58 \pm 4,42 \mu \mathrm{mol} H 2 \mathrm{O} 2 \mathrm{Eq} / \mathrm{L}, 9,40 \pm 6,58 \mu \mathrm{mol}$ $\mathrm{H} 2 \mathrm{O} 2 \mathrm{Eq} / \mathrm{L}, \quad 10,55 \pm 7,42 \mu \mathrm{mol} \quad \mathrm{H} 2 \mathrm{O} 2 \mathrm{Eq} / \mathrm{L}$ olarak bulundu. Elde ettiğimiz sonuçlarda travma modelinde TOS değeri en yüksek olup tedavi gruplarında daha düşük olmasına rağmen tüm gruplar arasında Kruskal Wallis analiz testine göre istatistiksel olarak anlamlı fark tespit edilmedi $(\mathrm{p}=0,08)$.

Mutlu ve ark. larının Çukurova Üniversitesi Neonatoloji bölümünde yapılan hiperoksi çalışmasında serum TAS düzeyleri kontrol grubu ile karşılaştırıldığında hiperoksiye maruz bırakılan diğer üç grupta da anlamlı derecede yüksek saptanmış (kontrol ile hiperoksi arasinda $p=0,031$, kontrol grubu ile NAC grubu arasinda $\mathrm{p}=0,001$ ve kontrol grubu ile vitamin grubu arasinda $\mathrm{p}<0,001)$. Hiperoksi grubu ile karşılaştırıldığında NAC grubunda ve vitamin grubunda da anlamlı derecede yüksek bulunmuş (p sırası ile 0,017 ve 0,014). NAC grubu ile vitamin grubu arasinda ise anlaml farklılık bulunmamış (21). Bizim çalışmamızda ise sham grubu, kontrol grubu, carnosol grubu, deksametazon grubu, carnosol-deksametazon kombine grubu serum TAS ortalama değerleri sirasiyla $1,39 \pm, 19 \mathrm{mmol}$ TroloxEq/L, 1,61 $\pm 0,50 \mathrm{mmol}$ TroloxEq/L, 1,33 $\pm 0,12 \mathrm{mmol}$ TroloxEq/L, 1,50 $\pm 0,13 \mathrm{mmol}$ TroloxEq/L,

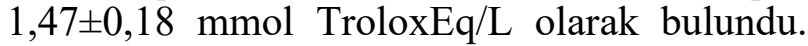
Tüm gruplar arasında Kruskal Wallis analiz testine göre istatistiksel olarak anlamlı fark tespit edilmedi. $(\mathrm{p}=0,167)$

Mutlu ve ark.larının çalışmasında serum OSI düzeyleri kontrol grubuna göre hiperoksi grubunda daha yüksek olmakla beraber istatistiksel olarak anlamlı değilmiş $(p=0,61)$. Hiperoksi grubu ile karşılaştırıldığında NAC ve vitamin grubunda OSI serum düzeyleri istatistiksel olarak düşük bulunmuş ( $p$ sirasıyla $0,002$ ve 0,032$)$. NAC ve vitamin grubu arasında farklılık saptanmamış $(p=0,74)$. Bizim çalışmamızda sham grubu, kontrol grubu, carnosol grubu, deksametazon grubu, carnosol 
ve deksametazon kombine grubu serum OSI ortalama değerleri sirasiyla $0,75 \pm 0,35 \mathrm{AU}$, $0,96 \pm 0,45 \mathrm{AU}, 0,55 \pm 0,30 \mathrm{AU}, 0,60 \pm 0,36 \mathrm{AU}$, $0,68 \pm 0,39$ AU olarak bulundu. Tüm gruplara ait serum OSI seviyelerinde Kruskal Wallis analizine göre istatistiksel olarak anlamlı fark saptanmadi $(\mathrm{p}=0,119)$.

Sonuç olarak akciğer kontüzyonunda mortalite ve morbiditenin azalması amaciyla erken dönemde carnosol ve deksametazon uygulanmasının etkinliğini araştırdığımız çalışmamızda özellikle patolojik sonuçlarımız değerlendirildiği zaman carnosol ve deksametazonun hücresel yanıtı düzenlediği, kontüzyonun klinik belirtilerini gerilettiği istatistiksel olarak anlamlı olacak şekilde tespit edildi. Biyokimyasal verilerde ise serum TOS düzeyinin travma modelinde en yüksek olup tedavi gruplarında daha düşük değerler olmasına rağmen tüm gruplar arasında Kruskal Wallis analiz testine göre istatistiksel olarak anlamlı fark tespit edilmedi $(p=0,08)$. Diğer biyokimyasal parametrelerde de istatistiksel olarak anlamlı fark tespit edilemedi. Elde edilen veriler tekrar değerlendirildiğinde travmaya uğramayan sham grubundaki ratların çoğunda bile patolojik bulgular elde edilmesi bizleri şaşırtmaktadır. Bu ratların çalışma öncesinde de akciğerlerinde konsolide alanların, pnömonik infiltrasyonların olduğunu düşündürmektedir. $\mathrm{Bu}$ sebeplerden dolay1 hassas bir şekilde ölçüm yapılan TAS ve TOS kitlerinden elde edilen bazı veriler normalinden yüksek olabilir ve bazı biyokimyasal sonuçların yanlış yorumlanmasına yol açabilmektedir.

İçinde bulunduğumuz yüzyılda, özellikle maliyet hasta müdahalesinde oldukça önemli bir yere sahiptir. Siçanlarda oluşturulan deneysel akciğer kontüzyonunda antioksidan carnosol ve deksametazon kullanımının akciğerde kontüzyon şiddetini ve hücre hasarını kısmi olsa da azalttığını gözlemledik. $\mathrm{Bu}$ nedenle morbiditesi ve mortalitesi yüksek olan akciğer kontüzyonunda antioksidan destek tedavi olarak carnosol ve deksametazonun akciğer kontüzyonu tedavi sürecini hızlandıracağına inanmaktayız. Ancak deney ratlar üzerinde çalışılmış olduğundan insanlar üzerinde aynı sonucun alınabileceği kesin değildir. Bu yöntemin etkinliğinin araştırılması için daha ileri ve farklı ajanlarla karşılaştırmalı çalışmalara ihtiyaç vardır.

\section{TEŞEKKÜR}

$\mathrm{Bu}$ çalışma, deney hayvanlarının bilimsel amaçla kullanılabilmesi için Süleyman Demirel Üniversitesi Tıp Fakültesi Etik Kurulundan onay alınarak (01.09.2016 tarih ve 02 say1lı karar) etik kurul kurallarına uygun bir șekilde Süleyman Demirel Üniversitesi Tip Fakültesi Deney Hayvanları Araştırma Laboratuvarı, Tibbi Biyokimya ve Tibbi Patoloji Anabilim Dalı Laboratuvarlarında gerçekleştirilmiştir. Ayrıca Süleyman Demirel Üniversitesi Bilimsel Araştırma Projeleri Koordinasyon Birimi tarafindan 4564-TU1-16 proje numarasi ile desteklenmiştir.

\section{KAYNAKLAR}

1.Altınok T. Akciğer Yaralanmaları. TTD Toraks Cerrahisi Bülteni 2010;1:55-9.

2.Eren MB, A. Toraks Travmaları. Ökten İG, A., editor: Sim Matbaacılık Ltd. Şti; 2003.

3.Öğüt S. Doğal antioksidanların önemi. Adnan Menderes Üniversitesi Ziraat Fakültesi Dergisi. 2014;11(1):25-30.

4.Johnson JJ. Carnosol: a promising anti-cancer and anti-inflammatory agent. Cancer letters. 2011;305 (1): $1-7$.

5.Yao J-H, Zhang X-S, Zheng S-S, Li Y-H, Wang L -M, Wang Z-Z, et al. Prophylaxis with carnosol attenuates liver injury induced by intestinal ischemia/reperfusion. World $\mathrm{J}$ Gastroenterol. 2009;15(26):3240-5.

6.Tian X-F, Yao J-H, Zhang X-S, Zheng S-S, Guo $\mathrm{X}-\mathrm{H}$, Wang L-M, et al. Protective effect of carnosol on lung injury induced by intestinal ischemia/ reperfusion. Surgery today. 2010;40(9):858-65.

7.Raghavendran K, Davidson BA, Helinski JD, Marschke CJ, Manderscheid P, Woytash JA, et al. A rat model for isolated bilateral lung contusion from blunt chest trauma. Anesthesia \& Analgesia. 
2005;101(5):1482-9.

8.Erel O. A new automated colorimetric method for measuring total oxidant status. Clinical biochemistry. 2005;38(12):1103-11.

9.Çalikoglu M, Tamer L, Sucu N, Coskun B, Ercan B, Gul A, et al. The effects of caffeic acid phenethyl ester on tissue damage in lung after hindlimb ischemia-reperfusion. Pharmacological research. 2003;48(4):397-403.

10.Desselle WJ, Greenhaw JJ, Trenthem LL, Fabian TC, Proctor KG. Macrophage cyclooxygenase expression, immunosuppression, and cardiopulmonary dysfunction after blunt chest trauma. Journal of Trauma and Acute Care Surgery. 2001;51(2):239-52.

11.Raghavendran K, Davidson BA, Woytash JA, Helinski JD, Marschke CJ, Manderscheid PA, et al. The evolution of isolated bilateral lung contusion from blunt chest trauma in rats: cellular and cytokine responses. Shock (Augusta, Ga). 2005;24 (2): 132 .

12. Yalçınkaya İ, Sayır F, Kurnaz M, Çobanoğlu U. Chest Trauma: Analysis Of 126 Cases. Ulus Travma Acil Cerrahi Derg. 2000;6(4):288-91.

13.Jones K. Thoracic Trauma: Surg Clin North Am; 1980. p. 957-81.

14.Stockmann U, Roscher R. Pulmonary contusion after blunt chest trauma--an experimental model (author's transl). Thoraxchirurgie, vaskulare Chirurgie. 1977;25(4):211-3.

15.Ocalan K, Solak O, Esme H, Sirmali M, Dilek $\mathrm{H}, \mathrm{Oz} \mathrm{G}$, et al. Efficacy of budesonide and interleukin-10 in an experimental rat model with isolated bilateral pulmonary contusion created by blunt thoracic trauma. European Journal of CardioThoracic Surgery. 2012 jun 24.

16.Roux P, Fisher RM. Chest injuries in children: an analysis of 100 cases of blunt chest trauma from motor vehicle accidents. Journal of pediatric surgery. 1992;27(5):551-5.

17.Pepe PE, Potkin RT, Reus DH, Hudson LD, Carrico CJ. Clinical predictors of the adult respiratory distress syndrome. The American Journal of Surgery. 1982;144(1):124-30.

18.Williams JS, Minken SL, Adams JT. Traumatic asphyxia--reappraised. Annals of surgery. 1968;167 (3):384.

19.Rocco PR, Souza AB, Faffe DS, Pássaro CP, Santos FB, Negri EM, et al. Effect of corticosteroid on lung parenchyma remodeling at an early phase of acute lung injury. American journal of respiratory and critical care medicine. 2003;168 (6):677-84.

20.Wigenstam E, Rocksén D, EkstrandHammarström B, Bucht A. Treatment with dexamethasone or liposome-encapsuled vitamin $\mathrm{E}$ provides beneficial effects after chemical-induced lung injury. Inhalation toxicology. 2009;21(11):958 $-64$.

21.Mutlu B, Narlı N. Deneysel olarak devamlı hiperoksi sonrası oluşturulan akciğer hasarının tedavisinde $\mathrm{E}+\mathrm{C}$ vitamini kombine tedavisi ile $\mathrm{N}$ Asetinsistein tedavisinin etkinliğinin değerlendirilmesi. 2011. 